Leadership and the Humanities, Vol. 4 No. 1, 2016, pp. 52-58

\title{
Interview
}

\section{Of war and words: a conversation about the humanities with General Martin Dempsey, 18th Chairman of the Joint Chiefs of Staff}

\author{
Interview by Noah Comet in collaboration with Commander Derek Handley
}

United States Naval Academy, Annapolis, MD, USA

\begin{abstract}
General Martin Dempsey, Chairman of the Joint Chiefs of Staff, is the highest-ranking officer in the United States armed forces. He is also a humanist with a master's in Irish literature from Duke University. For a brief time after earning that degree he taught English composition at the United States Military Academy at West Point. He peppers his speeches with allusions to Yeats, Faulkner, Didion, and others, and his humanities background is an enduring influence not only in his speaking, but in his perspective on the education of young men and women in the military. He was interviewed in April 2015 by two professors at the United States Naval Academy, Noah Comet and Commander Derek Handley.
\end{abstract}

Noah Comet: How has your undergraduate and graduate work - and your subsequent teaching - in English influenced your thinking as a military leader? That's our big question. But if it's okay, we'd to like to frame this question in a few different ways. First things first, can you talk a little about what drew you to an MA in literature and to your project on the Irish Literary Revival?

Gen. Martin Dempsey: I was drawn to learn more about being Irish by my grandmother. She was an immigrant. Both of my parents worked blue collar jobs; my father worked in an oil refinery in Bayonne, New Jersey, and my mother worked at a convenience store. So when they'd go to work, you know, Grandma would pull 'number one grandchild' upstairs (where she lived) and she made sure I knew what it meant to be Irish. It started out with Irish music and things like that. So I was always interested in my ethnicity.

When I was finishing up my time as an O-3 [Captain], I had a desire to go back to graduate school. Frankly, I didn't care what discipline; what I was looking for was a way for the Military Academy at West Point to invite me to come back to serve on the faculty. Two or three departments expressed an interest: the most prominent were History and English, and the English department gave me more options - more schools, and a wider aperture into which I could fit myself, so I chose English. I had always enjoyed the humanities, in any case. I went to Duke University for all the right reasons, which is to say, it was in the south, with a good basketball program [laughs]. Really, I went to Duke because it was a prominent school, and I thought it would be a challenging opportunity, and I was looking to challenge myself. And they actually didn't have a formal program in Irish literature, but, as I mentioned earlier, I'd always had this fascination. ([Aside] I asked the West Point department head, do you care what I study down 
here? And he said no, but you do have to take some composition because we're going to ask you to teach the Cadets how to write.) So, I built my own program around the Celtic Renaissance - roughly 1898 to 1922 - Yeats and Joyce and Shaw. And I took some Art History and History courses from the same period, as well as literature courses, and did as much work as I could in the two years allocated.

$N C$ : You often allude to literary texts in your public remarks; do you find yourself deriving insights from your reading in your day-to-day activities as Chairman? If so, how? If so, what texts?

$M D$ : The last question is probably an impossible question to answer, and you know that as well as I do - there are so many different places where you can find a metaphor for life. I mean, that's what literature is really all about, isn't it?

When I got to West Point as an instructor, we had a professor by the name of Jack Capps, who was the head of the English department. And he stood in front of the incoming class of new instructors and he held up two books. One was Webster's Dictionary, and the other one was the complete works of William Shakespeare. And he said this book (the dictionary) will give you the definition of a word, but this book (the Shakespeare) will help you understand what it means. And that stuck with me through my whole life. For example, if I'm having a challenge bringing the Joint Chiefs together or figuring out civil-military relations or what's making our country tick these days, something from Yeats might pop into my head: 'talent perceives differences, genius unity.' So I can encourage groups I'm with to understand that it's not enough just to point out our differences, but that real genius is in bringing people together.

$N C$ : You've mentioned in the past some of the ways your educational background sensitized you to cultural differences and made you a stronger communicator - can you comment on that today? Any other things that you feel this discipline taught you about leadership?

$M D$ : Well, for one thing, I learned how to learn. And I picked up things that I've used in this job. You know, the more senior you become [in the military], the less direct influence you have on people. As a Lieutenant or Ensign you can put everybody you control around a table and you can look them in the eye and you can have them turn the ship one way or the other - or the tank or the aircraft. But by the time you get to be me, I have almost zero direct influence. Even my personal staff rebels. [Laughter.] What I do have is enormous indirect influence - but, if and only if two things exist. One is relationships, and you can learn a lot about building relationships through reading. The other is the ability to communicate my ideas. In the White House Situation Room, for example, he or she with the most persuasive argument generally prevails. You can have a tremendous idea, but if you fumble the ball in delivering it, it will stay fumbled - nobody's going to pick it up for you.

And with my staff - every once in a while, I'll get a really long paper or PowerPoint briefing and someone will dutifully try to make me go through it, and I'll stop them and say you know what? You need to make this a lot crisper. Here's the standard: if Shakespeare can define love in fourteen lines of iambic pentameter with a rhymed couplet, you ought to be able to do a little better with ISIL.

I'm drawn to theater, too. Theater is really all about improvisation at some level, and I think what leaders do - good leaders - is they improvise. From a solid foundation, of course, that they get at places like Annapolis, Colorado Springs or West Point. But they do have the ability to improvise. 
Commander Derek Handley: Sir, did you ever feel that you had to justify getting a master's in English to your peers in the Army?

$M D$ : No, I don't think so. Because we're all part of the same profession. I think that question is more prominent at the undergraduate level. By the time you achieve a master's or a doctorate, that's become your way of life and that question loses a certain amount of relevance. And for us [in the military] it certainly loses relevance. For those Midshipmen and Cadets who decide that they're going to be career officers and setting aside the fact that some parts of the Navy have to have such a deep commitment to STEM - I think that for all your specialties, and for all of those that exist in the Army and Air Force, the study of the humanities invites disciplined thinking. I don't want to create an oxymoron here, but we're looking for a certain discipline in our thinking, but, again, tempered by an understanding that most of life is improvisational. So I've never felt I had to justify it. And in fact I've never even tried to justify it, which is probably a more powerful message than if I had.

$N C$ : What advice might you have, if any, for faculty teaching in the humanities? what themes or skills do you feel we should highlight in our courses to prepare future military and civic leaders?

$M D$ : That's such a profound question. Because on the one hand, it's our responsibility to raise the youth in our field classically, if you will. Everything we do at the academies is built on the foundation of tradition. You are told from the minute you enter - if you make it, it will be because you contribute to the tradition on which this institution was founded. This is what we call adding to the 'long gray line' at West Point. So you're obligated to educate the students classically - that takes you in one direction. And we're also trying to build leaders who are adaptable and improvisational and inquisitive. And not everyone's fire is lit by a classical education. In fact, fewer people's fires are probably lit by a classical education than by one that might seem to be a little more contemporary. So the delicate balance for me, when I was teaching - and I'm sure it's the same today - is, you know, how much do I bring them back to the tried-and-true classical works, like the works of Shakespeare or Faulkner, versus what's new and fresh and exciting today? Frankly, I've lost track of that a bit, so I've fallen back on my classical education, and from that foundation I find ways to make connections. Mostly because I don't have time right now to explore. But I'd say, fundamentally, if I were teaching, I'd still want to have a mixture of classical and contemporary, just so the students don't get the wrong impression about the humanities - they didn't end in 1922.

And the students really do need to know how to write. I didn't like teaching composition qua composition. Sometimes you have to do it, especially if you get a student who's just making up his or her own stuff [laughs], which I've had, and probably you have too.

$D H \& N C:$ Oh yes!

$M D$ : And then they say, 'but James Joyce gets away with it!' And I say, right - as soon as you publish your first novel, we'll allow you to do it too -

$N C:-$ but you, son, are no James Joyce.

$M D$ : Yeah! Anyway, I always felt it was better to teach writing as an instrument, not as an end in itself. So every bit of enjoyment I had in teaching English composition was because I was able to link it to something that allowed the students to discover something in literature. 
$N C$ : There again is that emphasis on communication and personal connection, which seems to be a big part of what you're saying today. You alluded to this a minute ago, but do you have time these days to read? If so, what do you reach for?

$M D$ : Yeah, I do. One thing I do as Chairman that I would certainly encourage my successor to do: I have a deliberate campaign of learning. I have a CAG - a Chairman's Action Group - and in there is a cell of individuals whose purpose is to make sure I keep learning. Sometimes it might be, say, economics, and they will convene a roundtable with the country's finest economists. [Laughs] I have enormous convening power it's still weird to me. If I ask to see someone, a hundred percent of the time, they'll come, or they'll allow me to come to them. Think to yourself - if you had that authority, what would you do with it? What I do with it is I try to bring people in who can surprise me with something. You know, there are places in my world where I don't want to be surprised - the Persian Gulf, for example. But there are places where I want to be surprised, too, at an outreach, or in my office at a roundtable with the best and brightest in a particular field, whether it's economics or technology or something else.

And I visit a lot of schools. Tomorrow I'm going to Harvard, to the JFK school. I've been to Duke and Notre Dame, Stanford, USC, ASU, and Texas A\&M. I try to get around the country to see what's going on in academia.

But principally, to answer your question, I have this group that forces me to learn. In fact, if it gets to be two or three weeks and I haven't done something like that, I get a bit scratchy about it - you know, when is my next campaign of learning event?

And the other thing is that I $d o$ read. Almost always on the road. When I'm in Washington, DC, frankly, my schedule's not my own. But when I'm on the road, I will frequently read a book or two. Not much literature lately, but a lot of reading.

$N C$ : Is teaching literature something you see yourself turning back to?

$M D$ : I don't know. In retirement I'd like to do something in academia. It'd probably be hard to go back to teaching English, or composition, but if I am lucky enough to have someone ask me to do something in, say, leader development, or, for that matter, strategic thinking, I'll probably use literature as the instrument to get the students to think about the issues.

DH: In a Wall Street Journal interview last year [April 1, 2014], you said 'remember, we have to see our friends, partners, and potential adversaries through the lens of who they are before we try to influence them.' That reminded me of the book The Power of Followership by Robert Kelley, in which he argues that we forget the ways in which leaders derive power from those who follow them - and that followers determine whether leaders succeed. I was just wondering how much of your military career has been impacted positively by the people you've led.

MD: Well, I just got named as one of Time's '100 Most Influential People in the World for 2015,' and I joked about it - I said, I don't know how that's possible: I'm not even the most influential person in my own house!

You know, the class of 1915 at West Point was called 'the class that stars fell on.' Thirty-six percent of the class became General Officers. Those classes [around that time] at West Point and Annapolis fundamentally led us through the Second World War. After 1915, when they graduated, there was the brief period of World War I, but then there was this huge period of incredibly scarce resources for the United States military, and then a rapid acceleration and mobilization for World War II, and that was only possible because the leaders had been nurtured through that period. So I've 
always felt that when you leave a unit - a ship in your case, a battalion in my case - what matters is not the gunnery scores or the maintenance record. Frankly, that takes care of itself if you focus on the people - the people are your legacy. I look back at how many of the Lieutenants became Battalion Commanders; how many of the Battalion Commanders became Brigade Commanders; how many of the Brigade Commanders became General Officers, and so forth. Or Sergeants, Sergeants First Class, First Sergeants, and Sergeants Major. That seems to me to be the better measure of a senior officer's career than how many stripes he's got on his sleeve.

$D H$ : We've talked about writing and communication, but is there anything else? - are there any intangibles about studying the humanities that you feel are important for leadership?

$M D$ : I think it makes you more interesting. [Laughter.] Even in congressional testimony. One time I was getting harangued about Iran and whether they were rational or not. And depending on how you answer that question, it'll guide your path on how to deal with Iran. So what flashed into my head was the famous Thucydides quote - that all nations act for one of three reasons: fear, honor or interest. Look, I said, you be the judge. Iran seems to be acting out in all three of those areas. They have their interests, which are in many cases counter to our own - the Islamic Revolution is not part of our value system. And they are fearful - and I articulated why I believe that to be the case. And I think they have a certain pride that derives from their notion of honor and their culture and their history. And I said on that basis, you can describe most nations. Most - there are a couple where I would think even Thucydides might have had it wrong. The point is, adding that bit of historical context to a conversation frankly makes it more persuasive. And if it doesn't make it more persuasive, it'll intimidate the hell out of people [laughs].

$N C$ : I think we're officially out of time, Sir, so thank you.

$D H$ : Thank you, Sir.

$M D$ : Thanks for what you're doing. You know, people always ask me, 'Do we really need the military academies?' And I have a long answer to that question, but one of the things that people forget is that in the rotational faculty, we have a way of refreshing our sense of professionalism and intellect, and that gets infused into the military - just like the thousand graduating Midshipmen infuse something into the military every year. I think it makes for a healthier environment.

\section{COMMENT FROM NOAH COMET}

As a civilian faculty member at the US Naval Academy, I find General Dempsey's perspective to be especially encouraging and illuminating. When I tell people that I teach British literature to Midshipmen, I am often met with incredulity. Why, after all, would Annapolis even need an English department if its mission is to groom future naval officers? What does Shakespeare have to do with aircraft carriers? As Dempsey makes clear, quite a bit.

Annapolis, like West Point and the Air Force Academy, has a vibrant English department comprised of a mix of civilians holding doctorates and officers typically holding or obtaining master's degrees. Like our peers anywhere else, we publish academic books and essays, novels and poems, op-eds and book reviews. Our research and teaching interests cover the gamut, from women's poetry to foreign film. 
Uniformed students and honorifics aside, what happens in our classrooms is no different from what happens at any other college.

Indeed, the only significant difference between our English courses and English courses everywhere is in what we ultimately produce: junior military officers who hold Bachelor of Science degrees (and this includes our English majors; the 'BS in English' joke is not lost on us here) and who can, if memory serves them, tell you what an iamb is or what they learned from reading The Bluest Eye. As one of my officer colleagues likes to say, the Midshipmen have a kind of radical freedom when it comes to choosing their majors. There is, as General Dempsey admits, a demand for STEM - someone in charge of a nuclear submarine needs to know a thing or two about chemistry - but because we have a required math- and science-heavy core curriculum and because 100 percent of our graduating seniors get jobs, the 'Mids,' as we call them, can choose a humanities major knowing that this choice will not disadvantage them. The General, himself a West Point graduate, is proof positive of this.

Before joining the Annapolis faculty I taught at a Big Ten university where, like many English professors, I often worried over the 'crisis in the humanities' and wrestled with the purpose of the classes I taught. What is surprising is that, since coming here to a place where one might expect little patience for the humanities, I spend much less time than before in existential quandary. Each semester, as I face a new roomful of future military leaders, I feel confident that what I am asking them to do will be of benefit to them and, through them, to myself and my countrymen, who hope for and deserve a thoughtful, prudent, and intelligent group overseeing our national defense. I'm not only going to help these young men and women to be more precise communicators in a profession where verbal ambiguity costs lives and public money; I'm also going to introduce them to texts and theories that will make them better thinkers who are aware of the powers and risks of metaphor, able to identify the workings of ideology, and sensitized to cultural differences and the constructedness of gender. This may be wishful thinking, but it gives clarity and purpose to what I do. As I remind skeptics, we ought to heed the adage that in segregating our warriors and intellectuals we are bound to find our fighting done by fools and our thinking done by cowards.

As an English PhD, I'm trained to be more cynical than this. In a pointed 2012 essay in Jacobin, Anthony Galluzzo, a former instructor at West Point (and, coincidentally, a grad student peer of mine), astutely questioned such a justification as the 'soft imperialist instrumentalization of literary study - a kind of weaponized sentimentalism' (Galluzzo 2012, para. 8). It is difficult to argue with this logic if one presumes that Midshipmen or Cadets will wield their Wordsworths and Hemingways like so many swords and shields. Am I teaching operatives of the military-industrial complex how to manipulate others and conceal their own misdoings with specious 'cultural empathy'? Am I providing a veneer of polite introspection to what is ultimately a crude and violent enterprise? Moreover, am I wronging my beloved authors and their texts?

Of course I don't think so. For one thing, we enjoy true academic freedom here, and the literature my colleagues and I tend to teach is not so readily perverted into propaganda. Poems like Wilfred Owen's 'Dulce Et Decorum Est' and Claude McKay's 'America,' and novels like Mary Shelley's Frankenstein, counsel against casual militarism, jingoism, and unchecked ambition. It would require a willful misreading of gargantuan proportions - or an act of bad faith - to put such texts into the service of empire. For another, it is worth noting that Mids and Cadets aren't programmable drones. The service academies have some of the lowest college acceptance rates in the nation and attract an overachieving group of scholar-athletes. Given their military inclinations, these students are certainly more prone than their 
civilian peers to accepting authority, but I have always found them nonetheless ready to interrogate received wisdom and scrutinize their own prejudices when called to do so. After all, the life of a military officer can be one of unpredictable movement that requires constant adaptability. Intransigence doesn't make rank and it certainly doesn't serve our country.

In General Dempsey's remarks, we see the proof of this: a strong emphasis on the humanities as instructive for leaders who must be able to think for themselves, improvise when needed, and regard the past as prologue.

I continue to wrestle with how best to implement these ideas in the classroom. Western literature is flush with case studies in leadership, from Agamemnon v. Achilles to Captains Ahab and Queeg, and beyond. It is an effective strategy to teach from these examples, and yet, in doing only that, we risk ignoring some of the most important elements of General Dempsey's commentary. Plot-level analysis of a character's flaws can make us more self-critical, certainly, and can help us to develop better foresight, but I'd argue that there is just as much value in studying works that have less to do with the practice of leadership per se and more to do with curiosity, innovative ways of seeing the world, understanding consciousness, or appreciating the power of words themselves. The Chairman favors Yeats, and indeed the bleak visionings of a poem like 'The Second Coming' can open up into a broad classroom conversation about the necessity of communication and connectedness (lest, per Yeats, 'the falcon cannot hear the falconer'). So too, Keats's sonnet 'On First Looking Into Chapman's Homer,' which anguishes over inclusivity, experience, and discovery, or Alice Walker's story 'Everyday Use,' which defines two competing modes for appreciating one's heritage, can occasion deep discussions about how one establishes a sense of belonging, how one relates to people with different values, and how language preconditions our relationships and the kinds of questions we are likely to ask each other. None of these works is expressly about leadership, and yet an aspiring leader will learn much from reading them.

Of course, the cultivation of creativity and imagination is another important aspect of a humanities education. After all, the best leaders help to create new opportunities for growth, new solutions to longstanding problems, and new ways to bring people together. We may look at the examples of successful and inventive humanities majors who have worked at the forefront of a broad spectrum of professions to see the truth in this. Ted Turner, Hank Paulson, Michael Eisner, Anne Mulcahy, Peter Thiel - the list goes on. In the words of Steve Jobs - certainly no stranger to creativity - 'innovation distinguishes between a leader and a follower.' And no discipline is better-suited than the humanities to reinforcing that principle. Devotees to STEM sometimes view humanities work as soft, but it is absolutely clear that inspiring young minds to wander a bit is one way to promote developments even in hard science, politics, or business. And even, per the General's example, in diplomatic and military affairs.

Perhaps this is all to say what General Dempsey's remarks already imply, vis-à-vis disciplined thinking and improvisation: that in teaching leadership through literature, one must emphasize pedagogy no less than curriculum. For a successful leader is measured not - or not only - by what s/he knows, but by how s/he thinks.

\section{REFERENCE}

Galluzzo, Anthony (2012), 'Sarah Lawrence, With Guns,' Jacobin, issue 7-8, available at: https://www.jacobinmag.com/2012/08/sarah-lawrence-with-guns/. 